\title{
HEIGHT-DIAMETER EQUATIONS FOR BRAZIL NUT INTERCROPPED WITH RUBBER TREE IN THE SOUTH OF MINAS GERAIS
}

\author{
Aldenir de Carvalho Caetano ${ }^{1}$, Sabina Cerruto Ribeiro ${ }^{2}$, Renato Luiz Grisi de Macedo ${ }^{3}$, \\ Bruna Anair Souto Dias ${ }^{4}$ \\ ${ }^{1}$ Agricultural Scientist, D.Sc., IFAM, Manaus, AM, Brasil - aldenir@ifam.edu.br \\ ${ }^{2}$ Forest Engineer, D.Sc., Depto. de Eng. Florestal, UNB, Brasília, DF, Brasil - sabinaribeiro@unb.br \\ ${ }^{3}$ Forest Engineer, D.Sc., Depto. de Ciências Florestais, UFLA, Lavras, MG, Brasil - rlgrisi @dcf.ufla.br \\ ${ }^{4}$ Forest Engineer, D.Sc., Curso de Eng. Florestal, UFPI, Terezina, PI, Brasil - brunasoutodias@ gmail.com
}

Received for publication: 26/06/2013 - Accepted for publication: 12/03/2014

\begin{abstract}
Brazil nut is a worldwide-recognized species due to its nuts, traded around the globe playing an important social and economic role in the Amazon. Several studies published information on issues related to nuts production and effects of seed gathering in the species regeneration. Nonetheless, to our knowledge there are no studies focusing on dendrometric parameters for Brazil nut outside its natural occurrence area. Thus, our study aimed to adjust height-diameter equations for Brazil nut intercropped with rubber tree in the South of Minas Gerais. Four standard models were tested using an ordinary least squares-regression analysis. The goodness-of-fit criteria used were the adjusted coefficient of determination $\left(\bar{R}^{2}\right)$, the percent standard error of estimate $\left(S E E_{\%}\right)$ and the residual distribution analysis. The best-fit equation for the estimation of height was from model $1\left(\bar{R}^{2}=0.950\right.$; $S E E_{\%}=9.768$ ). The adjusted height-diameter equations had comparable $\bar{R}^{2}$ and $S E E_{\%}$ to other published studies on Brazil nut trees and further species. The adjusted height-diameter equation provided by this study can give support to future forest mensuration and management researches with this species, especially in the South-Central region of Brazil.

Keywords: Bertholletia excelsa; height; Amazon.
\end{abstract}

\section{Resumo}

Equações hipsométricas para castanheira-da-amazônia cultivada em consórcio com seringueira no sul de Minas Gerais. A castanheira-da-amazônia é uma espécie reconhecida mundialmente por sua castanha, que é comercializada no mundo todo e tem um papel social e econômico importante na Amazônia. Diversos estudos publicaram informações sobre questões relacionadas com a produção das castanhas e os efeitos da coleta das mesmas sobre a regeneração dessa espécie. No entanto, até onde vai o nosso conhecimento, não existem estudos que avaliaram parâmetros dendrométricos da castanheira-daamazônia fora da sua área de ocorrência natural. Assim, este estudo teve como objetivo ajustar equações hipsométricas para castanheira-da-amazônia em consórcio com a seringueira no sul de Minas Gerais. Quatro modelos foram testados usando análise de regressão pelo método dos mínimos quadrados. Os critérios usados para a avaliação do ajuste foram o coeficiente de determinação ajustado $\left(\bar{R}^{2}\right)$, o erro padrão da estimativa $\left(S_{y x} \%\right)$ e a análise gráfica dos resíduos. A equação de melhor ajuste para a estimativa da altura foi o modelo $1\left(\overline{\mathrm{R}}^{2}=0,950 ; S_{y x} \%=9,768\right)$. As equações hipsométricas ajustadas tiveram $\bar{R}^{2}$ e $S_{y x} \%$ comparáveis a outros estudos publicados para castanheiras-da-amazônia e outras espécies nativas. A equação hipsométrica ajustada neste estudo pode dar suporte para futuras pesquisas de mensuração e manejo florestal dessa espécie, especialmente na região Centro-Sul do Brasil.

Palavras-chave: Bertholletia excelsa; altura; Amazônia.

\section{INTRODUCTION}

Brazil nut tree (Bertholletia excelsa Bonpl. - Lecythidaceae) occurs in non-flooded forests from Amazon, Guyana and Surinam (MORI; SWARTHOUT, 2007). It is an emergent tree that can achieve a diameter at breast height of up to $300 \mathrm{~cm}$ and reach height up to $50 \mathrm{~m}$ (ZUIDEMA; BOOT, 2002). Brazil 
nut trees are presently classified as vulnerable to extinction due to extensive seed gathering and illegal deforestation (PAIVA et al., 2011; INTERNATIONAL UNION FOR CONSERVATION OF NATURE, 2012).

The seeds of the Brazil nut trees play an important social and economic role in the Amazon, providing livelihood for many of its inhabitants. Frequently, Brazil nut is pointed out as one of the most profitable non-timber forest products (ORTIZ, 2002; WADT et al., 2005). This fact motivated the development of many studies focusing on the Brazil nut production and regeneration (KAINER et al., 2007; SCOLES; GRIBEL, 2012), population structure (WADT et al., 2005; SCOLES; GRIBEL, 2011) and effects of selective logging (GUARIGUATA et al., 2009; SORIANO et al., 2012).

However, a very small number of studies to date have published information on dendrometric parameters for Brazil nut (TONINI et al., 2005, 2008). Most of these few studies were performed in areas of natural occurrence of the species. The knowledge of mensuration characteristics of the Brazil nut outside its native distributional range is essential to support its future introduction in other regions of Brazil.

The relationship between tree diameter and height is of great importance to describe the forest structure (TEWARI; GADOW, 1999). Diameter at breast height is normally easily measured in the field. Nonetheless, depending on the vegetation type, the measurement of height may be a costly and time consuming operation. An alternative is to utilize height-diameter models. They are standard tools used to predict height usually solely based on the diameter at breast height.

Several studies proposed height-diameter models for commonly planted exotic species, such as Eucalyptus and Pinus (BARROS et al., 2002; TOMÉ et al., 2007; DONADONI et al., 2010; RIBEIRO et al., 2010). However, for native tree species these kinds of studies are not so common.

Thus, our study aimed to help bridge this knowledge gap by adjusting height-diameter equations for Brazil nut intercropped with rubber tree in the South of the State of Minas Gerais.

\section{MATERIAL AND METHOD}

The study was performed in an experimental area $\left(21^{\circ} 13^{\prime} 30^{\prime \prime} \mathrm{S}, 44^{\circ} 58^{\prime} 16^{\prime \prime} \mathrm{W}\right)$ at the Federal University of Lavras, located in Southern Minas Gerais State, Brazil. In Lavras, the mean temperature is $19.3{ }^{\circ} \mathrm{C}$ and the average annual rainfall is around $1.530 \mathrm{~mm}$, concentrated during the summer season (from December to February). Soils at the study site were Oxisol. The area was at an altitude of $931 \mathrm{~m}$.

\section{Seedling production and field experiment}

Seeds of Brazil nut tree (Bertholletia excelsa Bonpl.) were collected in Alta Floresta and Paranaíta, in Northern Mato Grosso State, in areas of natural occurrence of the species. Seedlings were grown under $50 \%$ shade at the nursery of the Department of Forest Sciences from the Federal University of Lavras. Seedlings underwent a stage of acclimatization, with the shading gradual withdrawal, twenty days before planting in the field. Rubber tree (Hevea brasiliensis (Willd ex A. Juss.) Muell Arg.) seedlings were purchased from reputable nurseries.

The first step of the field experiment was initiated in the summer of 1996. Prior to planting the area was cleaned and the attack of ants prevented by using baits. Superphosphate $(200 \mathrm{~g})$ and organic compost $(10 \mathrm{~L})$ were applied in each one of the $40 \times 40 \times 40 \mathrm{~cm}$ planting holes. Seedlings of the Brazil nut tree were planted in $3 \times 3 \mathrm{~m}$ spacing with a split-plot design with four replicates. A total of 24 split-plots were established, totaling 96 seedlings. Weed control was performed during the entire experiment period.

Three years later, in the summer of 1999 , the seedlings of rubber trees were planted in every two inter rows of Brazil nuts ( $6 \times 3 \mathrm{~m}$ spacing), initiating the intercropping of Brazil nut with rubber trees. The rubber tree experiment was carried out in randomized blocks composed of six treatments (clones PB 235; IAC 15; IAN 3193; PR 255; IPA 1 and RRIM 600), three repetitions with four seedlings for section, totalizing 72 plants. The $40 \times 40 \times 40 \mathrm{~cm}$ planting holes were initially filled with phosphate $(300 \mathrm{~g})$. Fifteen days after planting, $150 \mathrm{~g}$ of 20-5-20 NPK was top-dressed over each planting hole. Weed control was also regularly conducted.

\section{Data collection and modeling}

The adjustment of height-diameter models in this study focused only on the Brazil nut individuals. Tree mensuration was performed in 2012 (16 years after planting) on 77 individuals (19 died). All trees with Diameter at Breast Height $(\mathrm{dbh}) \geq 5 \mathrm{~cm}$ had the girth tape measured. Total tree height was measured with a telescopic measuring pole. A diameter distribution was built to verify the frequency of individuals in the different diameter size class. 
Four standard models (TROREY, 1932; CURTIS, 1967; PRODAN, 1968) were evaluated for the estimation of height using an ordinary least squares-regression analysis:

$$
\begin{aligned}
& \frac{\mathrm{dbh}^{2}}{\mathrm{~h}-1,3}=\beta_{0}+\beta_{1} \cdot \mathrm{dbh}+\beta_{2} \cdot \mathrm{dbh}^{2}+\varepsilon_{\mathrm{i}} \\
& \ln (\mathrm{h})=\beta_{0}+\beta_{1} \cdot \frac{1}{\mathrm{dbh}}+\varepsilon_{\mathrm{i}} \\
& \mathrm{h}=\beta_{0}+\beta_{1} \cdot \mathrm{dbh}+\beta_{2} \cdot \mathrm{dbh}^{2}+\varepsilon_{\mathrm{i}} \\
& \ln (\mathrm{h})=\beta_{0}+\beta_{1} \cdot \ln (\mathrm{dbh})+\varepsilon_{\mathrm{i}}
\end{aligned}
$$

where: $\quad$ dbh $=$ diameter at breast height in $\mathrm{cm}$;

$\mathrm{h}=$ total height of the tree in $\mathrm{m}$.

Models 2 and 4 were linearized and a correction factor $(C F)$ was applied in their estimated height values (Eq. 5) due to the differences between distributions of log-transformed and metric values (SPRUGEL, 1983). Using the corrected value of the predicted height in meters, the standard error of estimate $(S E E)$ was recalculated.

$$
\mathrm{CF}=\exp \left(\frac{\mathrm{SEE}^{2}}{2}\right)
$$

The selection of the best equation was based on the adjusted coefficient of determination $\left(\bar{R}^{2}\right)$, the percent standard error of estimate $\left(S E E_{\%}\right)$ and the analysis of residual distributions (DRAPER; SMITH, 1998). Data analyses were accomplished using STATISTICA software package version 8.0 (STATSOFT INC., 2008).

\section{RESULTS AND DISCUSSION}

Total tree height of Bertholletia excelsa individuals ranged from 4.6 to $15.5 \mathrm{~m}$, with an average of $12.3 \mathrm{~m}$ (Coefficient of variation - C. V. $=24.1 \%)$. The dbh also had a high variation $(5.9 \mathrm{~cm}$ to 29.2 $\mathrm{cm})$, with an average of $17.7 \mathrm{~cm}(\mathrm{C} . \mathrm{V} .=34.0 \%)$. The diameter distribution of the Brazil nut trees tends to an unimodal distribution and is skewed to the right (Figure 1). This tendency is typical of even-aged stands (HUSCH et al., 2003). The low abundance of Brazil nut trees in the diameter center class $16.3 \mathrm{~cm}$ is possibly the result of an accidental removal of trees. As mentioned before, in 16 years of experiment, 19 individuals died. Half of deaths occurred during the seedlings establishment phase, and the rest some years after due to an improper operation of a tractor.

Mean annual diameter and height increment is $1.10 \mathrm{~cm}$ and $0.77 \mathrm{~m}$, respectively. These values are smaller than the ones found by Tonini et al. (2005) for Brazil nut trees in homogeneous stands in Roraima $\left(\mathrm{MAI}_{\mathrm{dbh}}=1.9 \mathrm{~cm} ; \mathrm{MAI}_{\mathrm{h}}=1.6 \mathrm{~m}\right)$. Several studies point to values ranging from 0.14 to $0.40 \mathrm{~cm}$ per year (SILVA et al., 1996, 2002; VIEIRA et al., 2005). Nonetheless, the mean annual diameter increment found in this study is higher than the values reported for natural forests in the Amazon region.

The goodness-of-fit criteria of the four models tested are given in table 1 . The variance in the data explained by the fit, quantified by the adjusted coefficient of determination $\left(\bar{R}^{2}\right)$, ranged from 0.82 to 0.95 . The $S E E_{\%}$ varied between 9.746 and 11.455 . Among the models tested, model 1 had the best-fitting according to $\bar{R}^{2}$ and $S E E_{\%}$. Model 3 had a similar $S E E_{\%}$ as model 1 , but a smaller $\bar{R}^{2}$. The linearized models (2 and 4) presented a poorer fit in comparison with the others.

Besides $\bar{R}^{2}$ and $S E E_{\%}$, an analysis of the residual distribution was also performed (Figure 2). Excepting model 4, the remaining models had a similar residual distribution with a tendency to sub estimate height of trees with smaller diameters. In the observed vs. predicted values scatter plots, models 
1, 2 and 3 followed a similar pattern. Data points are relatively well distributed along the tendency line. In general, the equations tend to super estimate height values.

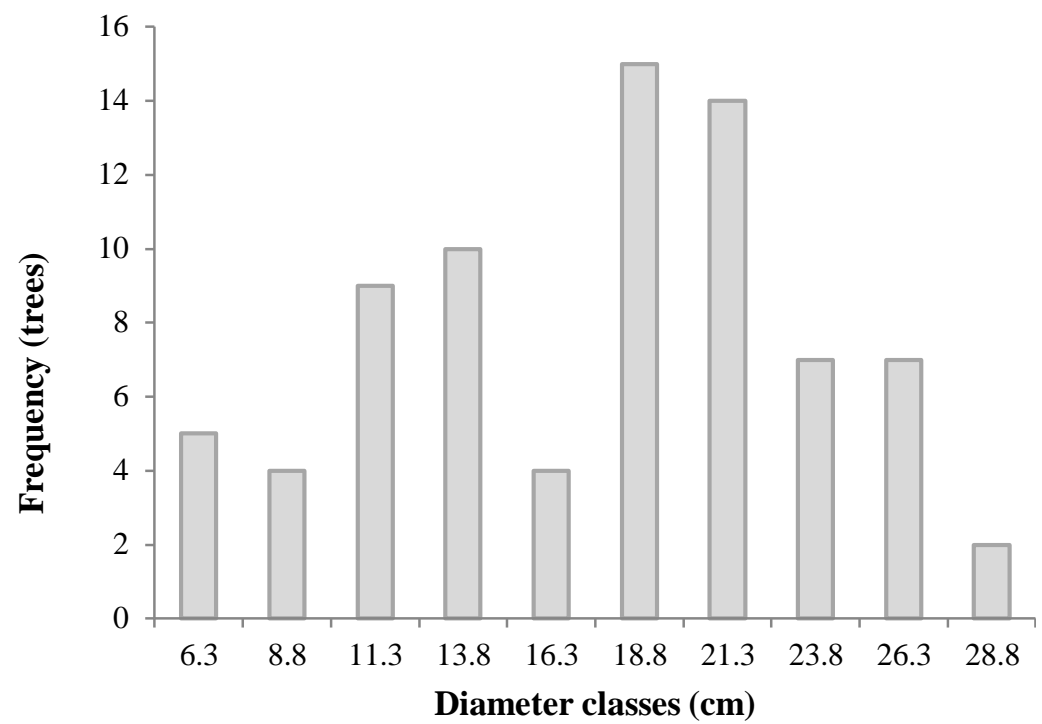

Figure 1. Diameter distribution of Brazil nut trees ( $2.5 \mathrm{~cm}$ dbh classes).

Figura 1. Distribuição diamétrica da castanheira-da-amazônia (classes de $2,5 \mathrm{~cm}$ de dap).

Table 1. Adjusted coefficient of determination $\left(\overline{\mathrm{R}}^{2}\right)$, standard error of estimate (SEE), percent standard error of estimate $\left(\mathrm{SEE}_{\%}\right)$ and correction factor $(\mathrm{CF})$ for the four regression models tested.

Tabela 1. Coeficiente de determinação ajustado $\left(\overline{\mathrm{R}}^{2}\right)$, erro padrão da estimativa (SEE), erro padrão da estimativa percentual (SEE\%) e fator de correção $(\mathrm{CF})$ para os quatro modelos de regressão testados.

\begin{tabular}{lccccccc}
\hline \multirow{2}{*}{ Model } & \multicolumn{3}{c}{ Coefficients } & $\overline{\boldsymbol{R}}^{2}$ & \multirow{2}{*}{$\boldsymbol{S E} \boldsymbol{E}$} & $\boldsymbol{S E E}_{\boldsymbol{\%}}$ & \multirow{2}{*}{$\boldsymbol{C} \boldsymbol{F}$} \\
\cline { 2 - 4 } & $\mathbf{b}_{\mathbf{0}}$ & $\mathbf{b}_{\mathbf{1}}$ & $\mathbf{b}_{\mathbf{2}}$ & & & & \\
\hline 1 & 8.0892 & -0.1235 & 0.0665 & 0.950 & 1.205 & 9.768 & \\
2 & 3.0357 & -8.4220 & & 0.858 & 1.211 & 9.818 & 2.082 \\
3 & -1.0099 & 1.2121 & -0.0232 & 0.836 & 1.202 & 9.746 & \\
4 & 0.0993 & 0.0351 & & 0.824 & 1.413 & 11.455 & 2.713 \\
\hline
\end{tabular}

According to the criteria used to select the best equation, model 1 was chosen as the best one for estimating height of Brazil nut trees. The adjusted height-diameter equations had comparable $\bar{R}^{2}$ and $S E E / S E E_{\%}$ to other published studies with Brazil nut trees and further species. Tonini et al. (2005) tested fifteen height-diameter models to estimate height in homogeneous stands of four different species in Cantá (RR), including Brazil nut trees. For the latter, the authors also pointed out model 1 as the best model to estimate height. They obtained a $\bar{R}^{2}$ equal to this study (0.95), albeit $S E E_{\%}$ was smaller $(4.53 \%)$.

Tonini et al. (2008) adjusted six height-diameter equations for two native populations of Brazil nut trees in Roraima. The authors found a $\bar{R}^{2}$ ranging from 0.54 to $0.70 ; S E E_{\%}$ varied from 5.9 to $13.6 \%$ (for the logarithmic models, the authors calculated a Furnival index). The goodness-of-fit criteria of our study is in general higher than the previous one.

Considering other species, Soares et al. (2011) tested two height-diameter models in eleven native forest species planted in Viçosa (MG). The species were Aspidosperma polyneurom M. Arg., Myracroduon urundeuva Fr. All., Hymenaea courbaril L., Lecythis pisonis Camb., Aspidosperma parvifolium A.CD., Pterigota brasiliensis Fr. All., Tabebuia serratifolia (Vahl.) Nich., Paratecoma peroba Kuhlm, Zeyheria tubrculosa (Vell.) Bur., Pterogyne nitens Tull. and Balfourodendron riedelianum (Engl.) Engl. The adjusted equations presented an average $\bar{R}^{2}$ of 0.746 and a $S E E$ that ranged from 1.19 to 4.11 . 
(A) Observed vs. predicted values

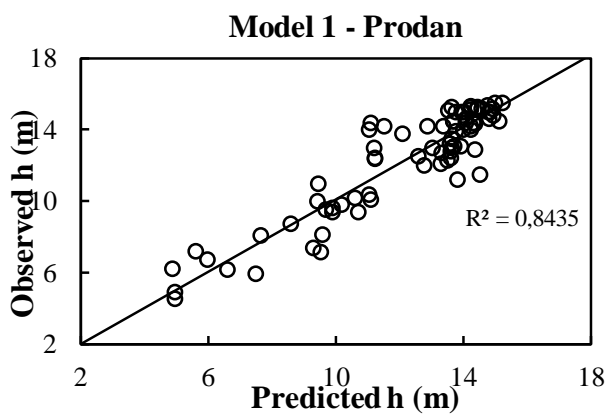

Model 2 - Curtis

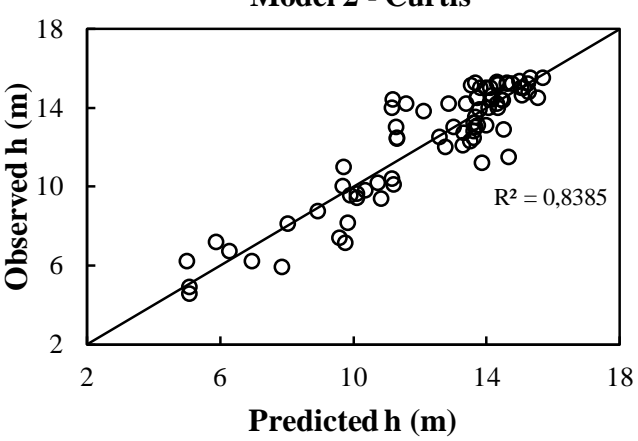

Model 3 - Parabolic

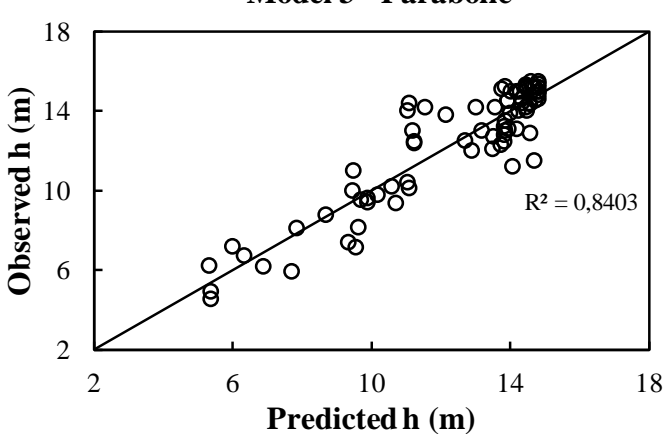

Model 4 - Stoffels

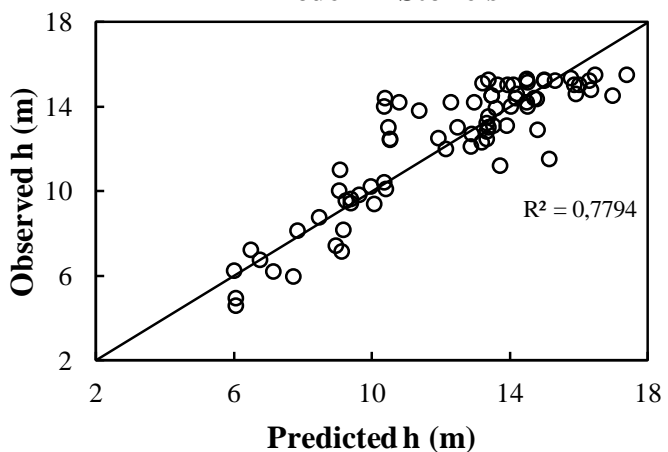

(B) Residual plots

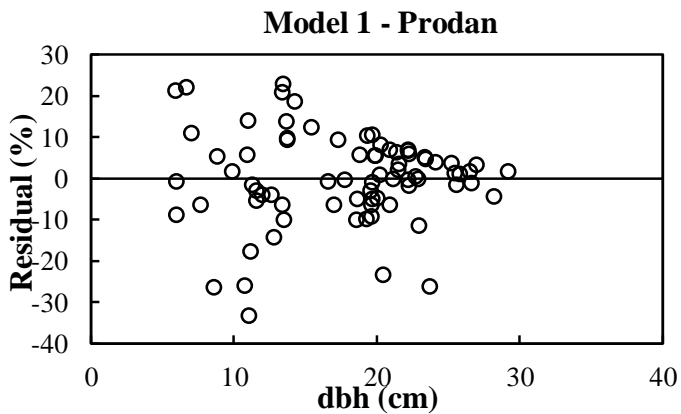

Model 2 - Curtis

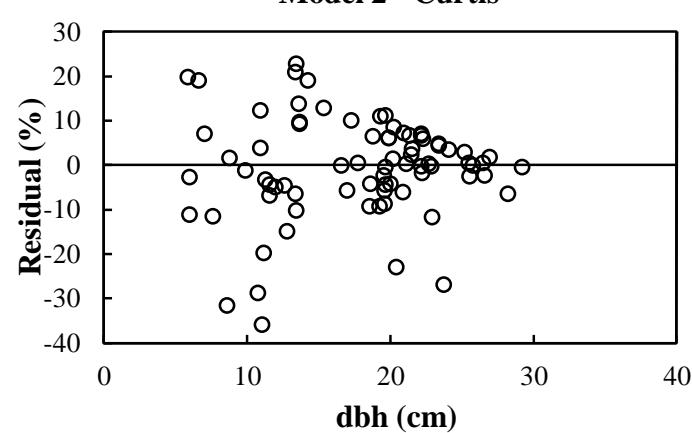

Model 3 - Parabolic

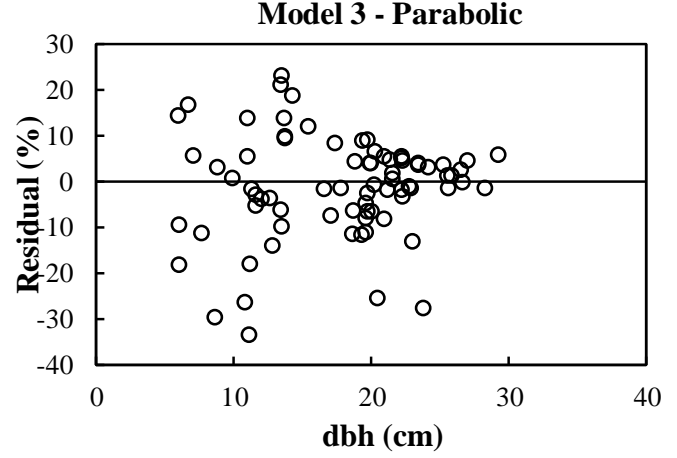

Model 4 - Stoffels

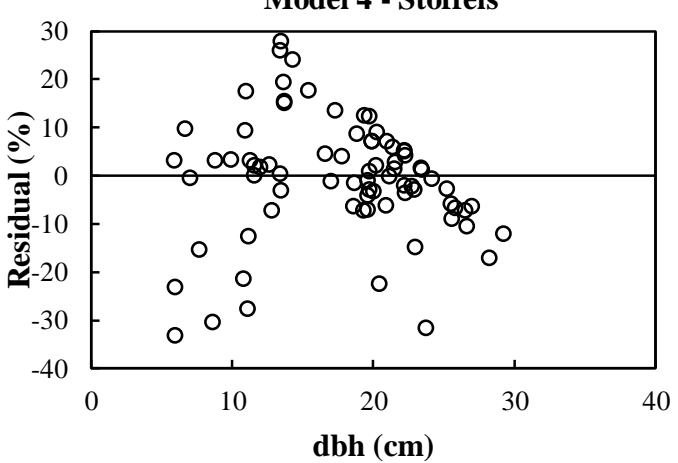

Figure 2. Observed vs. predicted values (A) and residual plots for the four models tested (B).

Figura 2. Gráfico de valores observados vs. estimados (A) e de resíduos para os quatro modelos testados (B). 
Santos et al. (2012) adjusted four height-diameter equations for Ocotea porosa (Nees \& Mart.) Barroso in Rio Negro (PR). For the best-fit equation, the authors related a $\bar{R}^{2}$ and a $S E E_{\%}$ of 0.85 and $11.86 \%$, respectively. The $\bar{R}^{2}$ and $S E E_{\%}$ obtained in this research are within the range of values reported in other studies.

\section{CONCLUSIONS}

- Among the four models tested, model 1 was selected as the best one to estimate height for Bertholletia excelsa in the conditions of the study site. We expect that the adjusted height-diameter equation provided by this study will give support to future forest mensuration and management research with this species, especially in the South-Central region of Brazil. The introduction of the Brazil nut outside its native habitat is a way to alleviate the extraction pressure on its population in the Amazon region. More studies should be conducted in order to determine silvicultural needs, best management practices and economical feasibility of Brazil nut plantations in different regions of Brazil.

\section{ACKNOWLEDGEMENTS}

To Conselho Nacional de Desenvolvimento Científico e Tecnológico and Fundação de Amparo à Pesquisa do estado de Minas Gerais for financial support.

\section{REFERENCES}

BARROS, D. A. de; MACHADO, S. A.; ACERBI JÚNIOR, F. W.; SCOLFORO, J. R. S. Comportamento de modelos hipsométricos tradicionais e genéricos para plantações de Pinus ooccarpa em diferentes tratamentos. Boletim Pesquisa Florestal, Colombo, n. 45, p. 3 - 28, 2002.

CURTIS, R. Height-diameter and height-diameter-age equations for second-growth Douglas-fir. Forest Science, Bethesda, v. 13, p. 365 - 375, 1967.

DONADONI, A. X.; PELISSARI, A. L.; DRESCHER, R.; ROSA, G. D. da. Relação hipsométrica para Pinus caribaea var. hondurensis e Pinus tecunumanii em povoamento homogêneo no Estado de Rondônia. Ciência Rural, Santa Maria, v. 40, p. 2499 - 2504, 2010.

DRAPER, N. R.; SMITH, H. Applied regression analysis. New York: John Wiley \& Sons, 1998. 706 p.

GUARIGUATAA, M.; LICONAB, J. C.; MOSTACEDOB, B.; CRONKLETONA, P. Damage to Brazil nut trees (Bertholletia excelsa) during selective timber harvesting in Northern Bolivia. Forest Ecology and Management, Amsterdam, v. 258, p. 788 - 793, 2009.

HUSCH, B.; BEERS, T. W.; KERSHAW JR., J. A. Forest mensuration. Hoboken: John Wiley \& Sons, $2003443 \mathrm{p}$.

INTERNATIONAL UNION FOR CONSERVATION OF NATURE. Americas Regional Workshop (Conservation \& Sustainable Management of Trees, Costa Rica, November 1996) 1998. Bertholletia excelsa. In: IUCN. Red list of threatened species. Version 2012.1. Disponível em: <http://www.iucnredlist.org>. Acesso em: 11/04/2013.

KAINER, K. A.; WADT, L. H. O.; STAUDHAMMER, C. L. Explaining variation in Brazil nut fruit production. Forest Ecology and Management, Amsterdam, v. 250, p. 244 - 255, 2007.

MORI, S. A.; SWARTHOUT, D. Brazil nut family (Lecythidaceae) in the New World. In: CLEVELAND, C. J.; SWARTHOUT, D. Encyclopedia of Earth. Washington, D.C.: Environmental Information Coalition, National Council for Science and the Environment, 2007. Disponível em: <http://www.eoearth.org/article/Brazil_nut_family_(Lecythidaceae)_in_the_New_World>. Acesso em: $12 / 02 / 2013$. 
ORTIZ, E. G. Brazil nut (Bertholletia excelsa). In: SHANLEY, P.; PIERCE, A. R.; LAIRD, S. A.; GUILLEN, A. S. Tapping the green market: certification \& management of non-timber forest products. Londres, 2002. p. 61 - 74.

PAIVA, P. M.; GUEDES, M. C.; FUNI, C. Brazil nut conservation through shifting cultivation. Forest Ecology and Management, Amsterdam, v. 261, p. 508 - 514, 2011.

PRODAN, M. Forest biometrics. Oxford: Pergamon, 1968, 447 p.

RIBEIRO, A.; FERRAZ FILHO, A. C.; MELLO, J. M.; FERREIRA. M. Z.; LISBOA, P. M. M; SCOLFORO, J. R. S. Estratégias e metodologias de ajuste de modelos hipsométricos em plantios de Eucalyptus sp. Cerne, Lavras, v. 16, p. 22 - 31, 2010.

SANTOS, A. T.; MATTOS, P. P.; BRAZ, E. M.; ROSOT, N. C. Equação de volume e relação hipsométrica em plantio de Ocotea porosa. Pesquisa Florestal Brasileira, Colombo, v. 32, p. 13 - 21, 2012.

SCOLES, R.; GRIBEL, R. Population structure of Brazil nut (Bertholletia excelsa, Lecythidaceae) stands in two areas with different occupation histories in the Brazilian Amazon. Human Ecology, New York, v. 39 , p. $455-464,2011$.

The regeneration of Brazil nut trees in relation to nut harvest intensity in the Trombetas River valley of Northern Amazonia, Brazil. Forest Ecology and Management, Amsterdam, v. 265, p. 71 - 81, 2012.

SILVA, J. N. M.; LOPES, J. C. A.; OLIVEIRA, L. C.; OLIVEIRA, R. P.; CARVALHO, J. O. P. Growth and yield studies in the Tapajós region, Central Brazilian Amazon. Commonwealth Forestry Review, Oxford, v. 75, p. 325 - 329, 1996.

SILVA, P. R.; SANTOS, J.; TRIBUZY, S. E.; CHAMBERS, Q. J.; NAKAMURA, S.; HIGUCHI. N. Diameter increment and growth patterns for individual tree growing in Central Amazon, Brazil. Forest Ecology and Management, Amsterdam, v. 166, p. 295 - 301, 2002.

SOARES, C. P. B.; MARTINS, F. B.; LEITE JÚNIOR, H. U.; SILVA, G. F.; FIGUEIREDO, L. T. M. Equações hipsométricas, volumétricas e de taper para onze espécies nativas. Revista Árvore, Viçosa, v. 35, p. 1039 - 1051, 2011.

SORIANO, M.; KAINER, K. A.; STAUDHAMMER, C. L.; SORIANO, E. Implementing multiple forest management in Brazil nut-rich community forests: effects of logging on natural regeneration and forest disturbance. Forest Ecology and Management, Amsterdam, v. 268, p. 92 - 102, 2012.

SPRUGEL, D. G. Correcting for bias in log-transformed allometric equations. Ecology, Ithaca, v. 64, p. 209 - 210, 1983.

STATSOFT INC. Statistica (data analysis software system), version 8.0, 2008.

TEWARI, V. P.; GADOW, K. V. Modelling the relationship between tree diameters and height using $\mathrm{S}_{\mathrm{BB}}$ distribution. Forest Ecology and Management, Amsterdam, v. 119, p. 171 - 176, 1999.

TOMÉ, M.; RIBEIRO, F.; FAIAS, S. Relação hipsométrica geral para Eucalyptus globulus Labill. em Portugal. Silva Lusitana, Lisboa, v. 15, p. 41 - 55, 2007.

TONINI, H.; ARCO-VERDE, M. F.; SÁ, S. P. P. Dendrometria de espécies nativas em plantios homogêneos no Estado de Roraima - Andiroba (Carapa guianensis Aubl), Castanha-do-Brasil (Bertholletia excelsa Bonpl.), Ipê-roxo (Tabebuia avellanedae Lorentz ex Griseb) e Jatobá (Hymenaea courbaril L.). Acta Amazonica, Manaus, v. 35, p. 353 - 362, 2005.

TONINI, H.; COSTA, P.; KAMINSKI, P. E. Estrutura e produção de duas populações nativas de castanheira-do-brasil (Bertholletia excelsa O. Berg) em Roraima. Floresta, Curitiba, v. 38, p. 445 - 457, 2008. 
TROREY, L. G. A mathematical method for the construction of diameter height curves based on site. The Forestry Chronicle, Ottawa, v. 8, p. 121 - 132, 1932.

VIEIRA, S.; TRUMBORE, S.; CAMARGO, P. B.; SELHORST, D.; CHAMBERS, J. Q.; HIGUCHI, N.; MARTINELLI, L. A. Slow growth rates of Amazonian trees: consequences for carbon cycling. Proceedings of the National Academy of Sciences of the United States of America, Washington, v. 102 , p. $18502-18507,2005$.

WADT, L. H. O.; KAINER, K. A.; GOMES-SILVA, D. A. P. Population structure and nut yield of a Bertholletia excelsa stand in Southwestern Amazonia. Forest Ecology and Management, Amsterdam, v. 211, p. 371 - 384, 2005.

ZUIDEMA, P. A.; BOOT, R. G. A. Demography of the Brazil nut tree (Bertholletia excelsa) in the Bolivian Amazon: impact of seed extraction on recruitment and population dynamics. Journal of Tropical Ecology, Cambridge, v. 18, p. 1 - 31, 2002. 